DOI 10.37882/2223-2974.2020.09.22

\title{
КОНКУРЕНТОСПОСОБНОСТЬ И СОТРУДНИЧЕСТВО В СФЕРЕ УСЛУГ ЖИЛИЩНО-КОММУНАЛЬНОГО ХОЗЯЙСТВА: ТЕОРИЯ, МЕТОДОЛОГИЯ, ЗАКОНОДАТЕЛЬСТВО, ПРАКТИКА (НА ПРИМЕРЕ СЕВЕРНЫХ РЕГИОНОВ)
}

\begin{abstract}
COMPETITIVENESS AND COOPERATION IN THE FIELD OF HOUSING AND COMMUNAL SERVICES: THEORY, METHODOLOGY, LEGISLATION, PRACTICE (ON THE EXAMPLE OF NORTHERN REGIONS)
\end{abstract}

V. Tikhomirova

Summary: The article discusses approaches to the definition of competitiveness and cooperation in the social sphere. An analysis of the state of the housing and communal services industry in the northern regions is given on the basis of indicators such as the supply of communal resources - cold water supply, heat supply, wastewater disposal in dynamics from 2016 to 2019. The main problems of the state of this branch of services have been identified: high wear and tear of water and heat supply facilities; low quality of services provided to the population, along with high service costs and low collection rates; growth or understatement of tariffs. It is determined that in many regions of the Far North of Russia, the established target indicators of the private market for goods, works, services in the market of housing and communal services have not been achieved, hence the competition in this type of economic activity is defined as weak. Conclusions and proposals are made that allow achieving the target indicators of the competitiveness of the northern regions.

Keywords: competitiveness, cooperation, housing and communal services, water supply, heat supply, water disposal.
Тихомирова Валентина Валентиновна

К.э.н., Институт Сочиально-Экономических и Энергетических Проблем Севера Коми Научного Центра Уральского Отделения Российской Академии Наук, г. Сыктывкар, Россия tikhomirova@iespn.komisc.ru

Аннотация: В статье рассмотрены подходы к определению конкурентоспособности и сотрудничества в социальной сфере. Дан анализ состояния отрасли жилищно-коммунального хозяйства северных регионов на основе таких показателей как, поставка коммунального ресурса - это холодное водоснабжение, теплоснабжение, водоотведение в динамике с 2016 по 2019 годы. Выявлены основные проблемы состояния данной отрасли услуг: высокий износ объектов водоснабжения и теплоснабжения; низкое качество услуг предоставляемых населению, наряду с высокой стоимостью обслуживания и низким уровнем собираемости платежей; рост или занижение тарифов. Определено, что во многих регионах Крайнего Севера России установленные целевые индикаторы частного рынка товаров, работ, услуг на рынке жилищно-коммунальных услуг не достигнуты, отсюда конкуренция, по данному виду экономической деятельности, определяется как слабая. Сделаны выводы и предложения, позволяющие достижению целевых показателей конкурентоспособности северных регионов.

Ключевые слова: конкурентоспособность, сотрудничество, жилищно-коммунальное хозяйство, водоснабжение, теплоснабжение, водоотведение.

го самоуправления. Указ Президента РФ «Об основных направлениях государственной политики по развитию конкуренции» определил цели совершенствования государственной политики: повышение удовлетворенности потребителей за счет расширения ассортимента товаров, работ, услуг, повышения их качества и снижения цен; повышение экономической эффективности и конкурентоспособности хозяйствующих субъектов; стабильный рост и развитие многоукладной экономики, снижение социальной напряженности в обществе, обеспечение национальной безопасности [1].

Такая трансформация экономической системы подразумевает поступательное развитие производственных взаимоотношений между конкурирующими субъектами 
и государством, а также изменение целевых установок структуры всей системы экономики. На XIX Всемирном фестивале молодежи и студентов в Сочи Президент В.В. Путин призвал сменить соперничество на сотрудничество и партнерство [2]. В связи с этим представляется целесообразным и назревшим переосмыслить соотношение категорий «конкурентоспособность» и «сотрудничество», выступающих как поставленные социальные стратегические цели, направленные на равноправие и социальное дружелюбие.

\section{Исследование содержания понятий «конкурентоспособность» и «сотрудничество»}

Анализ содержания категорий «конкурентоспособность» и «сотрудничество» мы рассмотрим с позиций экономико-социологического подхода, в рамках которого обзору подлежат взаимодействия как между конкурирующими агентами» [3], так и государством в развитии социальной сферы. Понятия «конкурентоспособность» и «сотрудничество» по-разному трактуется зарубежными и отечественными исследователями.

Повышение конкурентоспособности фирмы в современных условиях М. Портер свел к чрезвычайно содержательной формулировке: «Быть непохожим», т.е. найти альтернативное решение задачи, выгодно отличающее данный экономический субъект от других аналогичных субъектов на рынке и тем самым уменьшить уровень конкурентной борьбы [4].

В своей теории ему вторят исследователи Дж. Робинсон и Э. Чемберлин, которые считали, что конкурентоспособность, это способность обходить борьбу, развивая новые рынки дифференцированной продукции. [5].

В работах Й. Шумпетера и П. Ромера конкурентоспособность предприятия также «определяется способностью создавать новые технологии, новые рынки и идеи». [6].

Все выше обозначенные трактовки в своей основе отмечают наиболее важной новаторскую роль конкурентоспособности, основанную на интеллектуальном лидерстве и исключающую борьбу.

В России понятие «конкурентоспособность» исследуется относительно недавно. Экономисты выделяют основные признаки, раскрывающие сущность категории «конкурентоспособность»:

- конкурентоспособность проявляется на рынке (товаров, работ, услуг) [7];

- распространяется как на объект, так и на субъект рыночных отношений [7];

- имеет определенную конкурентную среду (количественная оценка экономических объектов, с по- мощью которой определяется уровень конкурентоспособности) [8];

- основой для определения конкурентоспособности выступают идентичные ключевые показатели у конкурента, определяющие социальный эффект (способность удовлетворять человеческие потребности) [9];

- имеет общую законодательную, правовую, нормативную, научно-методическую базу и информационное пространство [10];

Сегодня принципиально новые формы взаимодействия бизнеса становятся важнейшим фактором их конкурентоспособности, а человеческие ресурсы успешно реализуются по большей части в результате совместного сотрудничества. Сотрудничество выступает как механизм регулирования рыночных отношений, способствует развитию не только производства, но и человеческого капитала, уровню и качеству жизни населения и в этом смысле является важным фактором повышения конкурентоспособности [11].

За рубежом теорию сотрудничества между конкурирующими субъектами предложил Ф. Хайек [12]. Он увидел, что конкурирующие субъекты находятся в общем информационном пространстве, созданном всеми экономическими субъектами. На информационной природе конкурентоспособности акцентируют свое внимание и И. Кирцнер, Л. Мизесон, Ф. Найтон, П. Друкер [13].

Сотрудничество, как форма рыночных отношений между субъектами было предложено в концепции О. Уильямсона. Он назвал их «гибридными структурами» направленными на «совместное создание дополнительных ценностей» [14].

В России сотрудничество в большей степени осуществляется во взаимодействии государства и бизнеса. Однако содержание, формы и способы эффективного применения такого взаимодействия исследованы недостаточно. В научной литературе выделяют следующие основные формы сотрудничества:

- заключение договоров (реализуются на основе концессионных отношений);

- проведение конкурсов;

- взаимодействие государственного и частного капитала, осуществляемое путем формирования кластеров;

- сотрудничество государства и бизнеса в развитии социальной сферы, которое мы рассмотрим в данном исследовании, что в условиях пандемии особенно актуально.

Основополагающим принципом государственной политики является сокращение доли хозяйствующих субъектов контролируемых государством, в общем ко- 
личестве хозяйствующих субъектов, осуществляющих деятельность на рынках товаров и услуг. Утвержден Национальный план развития конкуренции в Российской Федерации на 2018 - 2020 годы. Его мероприятия направлены на достижение ключевых показателей, одним из которых является увеличение к 2020 году доли закупок, участниками которых являются социально ориентированные некоммерческие организации осуществляющие деятельность, направленную на решение социальных проблем, развитие гражданского общества в Российской Федерации в сфере государственного и муниципального заказа не менее чем в два раза по сравнению с 2017 годом. [15].

В настоящее время социальная сфера имеет легальное толкование в соответствии со «Стандартом развития конкуренции в субъектах РФ» где социальная значимость отраслей социальной сферы определяется с учетом сформированного перечня приоритетных и социально значимых региональных рынков, направленных на повышение уровня жизни населения [16].

\section{Анализ конкурентоспособности жилишно-коммунального хозяйства северных регионов}

В соответствии с Жилищным кодексом Российской Федерации от 29.122004 № 188-ФЗ определено три способа управления, при котором собственники помещений могут осуществлять обязательства по управлению общим имуществом: непосредственное управление; управление через товарищество собственников жилья; управление через управляющую организацию. В третьей главе Федерального закона от 06.10.2003 № 131-Ф3 «Об общих принципах общего самоуправления в Российской Федерации» вопросы жилищно-коммунального хозяйства относятся к ведению местного самоуправления и являются приоритетом государственной политики в этой сфере услуг. Отсюда, главным оценочным показателем конкурентоспособности регионов стала доля полезного отпуска государственных и муниципальных унитарных предприятий к общему полезному отпуску в конкретном субъекте РФ. Если ресурсоснабжением занимаются частные, а не государственные (ГУПы) или муниципальные предприятия (МУПы), то можно считать, что развитие конкуренции в регионе удалось. В соответствии с Указом Президента РФ «Об основных направлениях государственной политики по развитию конкуренции» № 618 от 21 декабря 2017 года, в 2019 году установлена цель, чтобы ГУПы и МУПы обеспечивали не более 20 \% жилищно-коммунальных услуг в регионе. В 2020 году планируется сократить показатели до $10 \%$. Контроль в таких отраслях жилищно-коммунального хозяйства (ЖКХ) как теплоснабжение, водоснабжение и водоотведение осуществляет Федеральная антимонопольная служба России. Она принимает меры по пред- упреждению и пресечению нарушений антимонопольного законодательства хозяйствующими субъектами и органами власти.

В данной статье мы рассмотрим конкурентоспособность северных регионов в жилищно-коммунальной сфере на основе таких показателей как, поставка коммунального ресурса - это холодное водоснабжение, теплоснабжение и водоотведение в динамике с 2016 по 2019 годы.

\section{Водоснабжение}

Специфика систем водоснабжения и водоотведения в условиях Крайнего Севера, где часть территорий находится за Северным полярным кругом, напрямую связана с климатическими риск - условиями и экономическими факторами. Это дороговизна и дефицит электроэнергии, кадровая обеспеченность, непостоянные транспортные связи, характер производства, застройка поселений, мощность предприятий, условия водоотведения с целью предохранения сетей от промерзания, мощность и сезонные особенности режима источников водоснабжения, уклад жизни и низкая плотность населения. В связи с этим уровень конкурентоспособности от региона к региону различен и имеет объективные причины.

В нормативном рейтинге самые высокие целевые показатели конкуренции в сфере холодного водоснабжения в 2019 году выявлены в таких регионах Севера как Ямало-Ненецкий автономный округ $(0,72)$, Архангельская область $(4,45)$, Республика Саха $(8,53)$, Республика Карелия $(10,81)$, Республика Коми $(12,98)$, Мурманская область $(19,33)$. В данных северных регионах доля полезного отпуска государственных и муниципальных унитарных предприятий к общему полезному отпуску в конкретном субъекте составила не более $20 \%$, что соответствует целевым установкам развития конкуренции.

Очень низкая конкурентоспособность зафиксирована в Камчатском крае $(89,46)$, Магаданской $(86,12)$ и Сахалинской $(78,10)$ областях, Ханты-Мансийском $(56,75)$, Чукотском $(55,62)$ и Ненецком $(42,38)$ автономных округах, где плотность населения колеблется от 01 до 07 чел. на квадратный километр. В данных регионах доля государственных и муниципальных унитарных предприятий составила от 90,0\% до 43,0\% (таб.1).

За последние четыре года (2016-2019) развитие конкуренции в холодном водоснабжении по регионам Севера России происходило неравномерно и скачкообразно (рис.1). Наибольшие количественные изменения в сторону целевых установок были достигнуты в Мурманской $(-60,43)$ и Архангельской $(-15,58)$ областях. 
Таблица 1

Развитие конкуренции в холодном водоснабжении по регионам Севера России, за 2016-2019 гг., \%*

\begin{tabular}{|c|c|c|c|c|c|}
\hline \multirow{2}{*}{ Регионы } & \multicolumn{4}{|c|}{ Доля полезного отпуска ГУП/МУП по отношению к общему полезному отпуску в субъекте РФ, \% } & \multirow{2}{*}{$\begin{array}{c}\text { Изменение показателя } \\
\text { за 2016-2019 гг., п.п. }\end{array}$} \\
\hline & 2016 & 2017 & 2018 & 2019 & \\
\hline Республика Карелия & 11,83 & 11,47 & 11,23 & 10,81 & $-1,02$ \\
\hline Республика Коми & 13,61 & 13,38 & 12,87 & 12,98 & $-0,63$ \\
\hline Архангельская область & 20,03 & 19,62 & 18,68 & 4,45 & $-15,58$ \\
\hline Ненецкий АО & 37,85 & 38,50 & 37,55 & 42,38 & 4,53 \\
\hline Мурманская область & 79,76 & 33,98 & 34,36 & 19,33 & $-60,43$ \\
\hline Ханты-Мансийский А0 & 61,69 & 59,08 & 58,33 & 56,75 & $-4,94$ \\
\hline Ямало-Ненецкий А0 & 0,88 & 0,74 & 0,70 & 0,72 & $-0,16$ \\
\hline Республика Саха (Якутия) & 11,17 & 8,72 & 7,79 & 8,53 & $-2,64$ \\
\hline Камчатский край & 52,27 & 87,76 & 87,21 & 89,46 & 37,19 \\
\hline Магаданская область & 79,76 & 79,54 & 78,17 & 86,12 & 6,36 \\
\hline Сахалинская область & 67,48 & 77,69 & 76,35 & 78,10 & 10,62 \\
\hline Чукотский АО & 24,00 & 24,77 & 47,52 & 55,62 & 31,62 \\
\hline
\end{tabular}

*Расчеты автора по данным Федеральной антимонопольной службы РФ.

Электронный ресурс. Режим доступа: https://fas.gov.ru

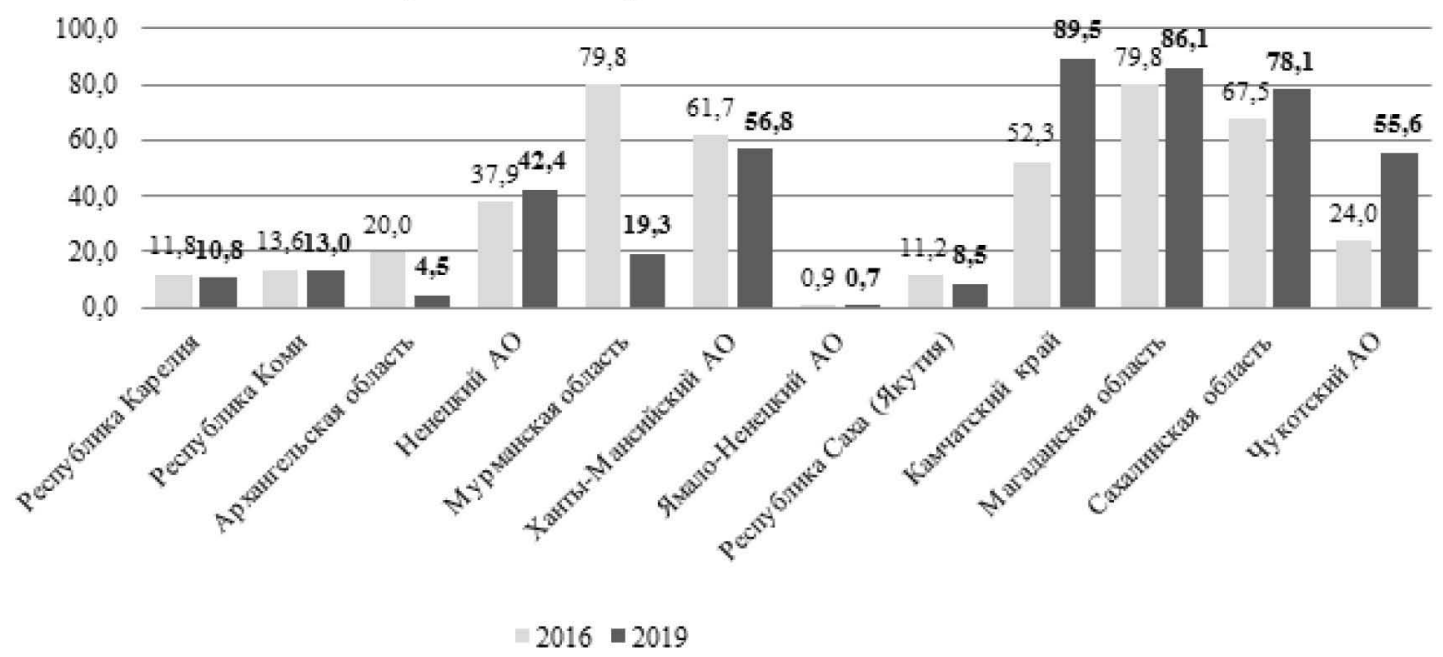

Рис. 1. Изменение показателя развития конкуренции в холодном водоснабжении по регионам Севера России, за 2016-2019 гг., \%

Значительно превышен пороговый целевой показатель в сторону государственных и муниципальных предприятий в Камчатском крае $(+37,19)$, Чукотском автономном округе $(+31,62)$ и в Сахалинской области $(+10,62)$, причем такая тенденция наблюдается в течение всего выше обозначенного периода. Низкая конкурентоспособность отмечается также в Магаданской области и Ненецком автономном округе.

\section{Водоотведение}

Лидерами конкуренции в сфере водоотведения стали: Ямало-Ненецкий автономный округ $(0,63)$, Республика Карелия $(7,00)$, Республика Саха $(7,73)$, Республика Коми (9,37), Архангельская область $(11,35)$.
По данным Федеральной антимонопольной службы России, крайне низкие показатели в сфере водоотведения зафиксированы в Чукотском (94,88), Ханты-Мансийском $(60,80)$ и Ненецком $(90,52)$ автономных округах, в Камчатском крае $(88,68)$, а также в Магаданской $(87,98)$, Сахалинской $(81,84)$ и Мурманской $(51,92)$ областях (таб.2).

Динамика достижения показателя водоотведения (доля в 2016 году - доля в 2019 году) также показала скачек в сторону государственных и муниципальных организаций в Камчатской крае $(+25,75)$, Магаданской $(+11,42)$ и Сахалинской $(10,81)$ областях (рис. 2).

Целевого показателя достигла Архангельская область, снизив участие государственных структур в поставке коммунального ресурса в два раза с 21,0 до 11,4\%. 
Развитие конкуренции в водоотведении по регионам Севера России, за 2016-2019 гг., \%*

\begin{tabular}{|c|c|c|c|c|c|}
\hline \multirow{2}{*}{ Регионы } & \multicolumn{4}{|c|}{ Доля полезного отпуска ГУП/МУП по отношению к общему полезному отпуску в субъекте РФ, \% } & \multirow{2}{*}{$\begin{array}{c}\text { Изменение показателя } \\
\text { за 2016-2019 гг., п.п. }\end{array}$} \\
\hline & 2016 & 2017 & 2018 & 2019 & \\
\hline Республика Карелия & 8,08 & 7,26 & 7,14 & 7,00 & $-1,08$ \\
\hline Республика Коми & 9,79 & 10,72 & 9,80 & 9,37 & $-0,42$ \\
\hline Архангельская область & 21,02 & 21,63 & 21,92 & 11,35 & $-9,67$ \\
\hline Ненецкий АО & 90,25 & 90,71 & 89,98 & 90,52 & 0,27 \\
\hline Мурманская область & 53,67 & 54,05 & 51,17 & 51,92 & $-1,75$ \\
\hline Ханты-Мансийский А0 & 60,07 & 59,61 & 59,78 & 60,80 & 0,73 \\
\hline Ямало-Ненецкий АО & 0,67 & 0,67 & 0,63 & 0,63 & $-0,04$ \\
\hline Республика Саха (Якутия) & 7,56 & 7,56 & 8,34 & 7,73 & 0,17 \\
\hline Камчатский край & 62,93 & 81,13 & 80,09 & 88,68 & 25,75 \\
\hline Магаданская область & 76,56 & 76,60 & 75,74 & 87,98 & 11,42 \\
\hline Сахалинская область & 71,03 & 82,51 & 80,91 & 81,84 & 10,81 \\
\hline Чукотский АО & 92,16 & 91,87 & 95,21 & 94,88 & 2,72 \\
\hline
\end{tabular}

*Расчеты автора по данным Федеральной антимонопольной службы РФ.

Электронный ресурс. Режим доступа: https://fas.gov.ru

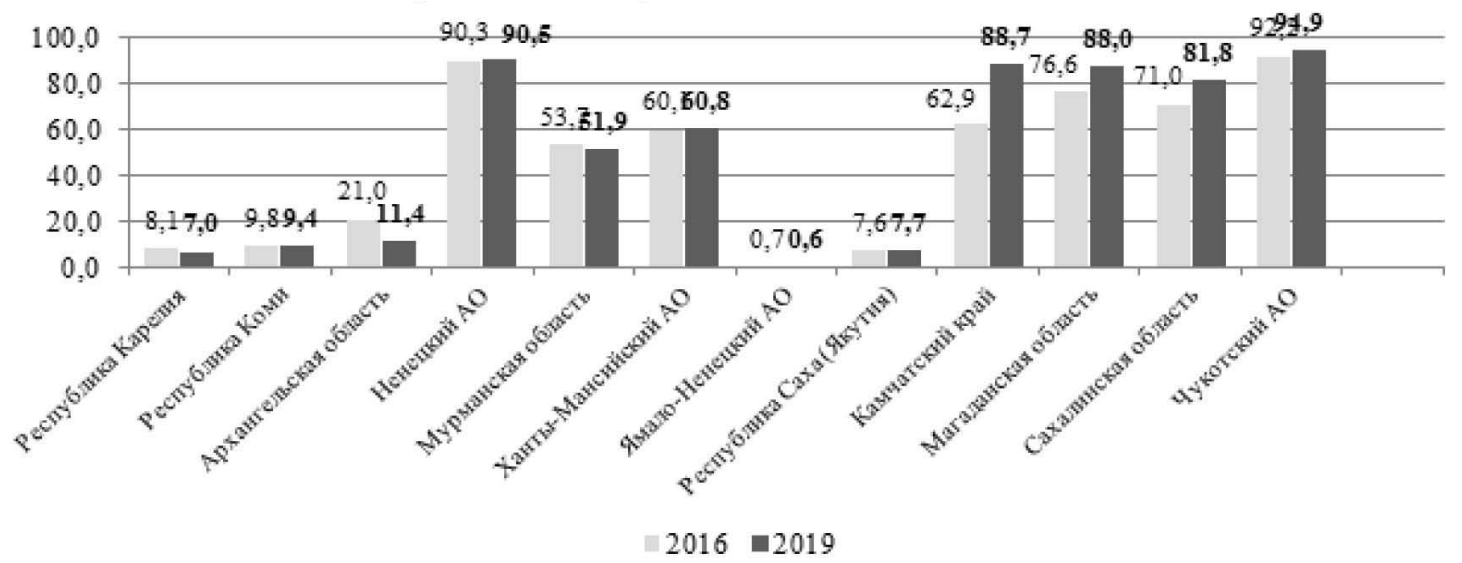

Рис. 2. Изменение показателя развития конкуренции в водоотведении по регионам Севера России, за 2016-2019 гг., \%*

\section{Теп^оснабжение}

В 2019 году доля наименьшего полезного отпуска государственных и муниципальных унитарных предприятий, занимающихся теплоснабжением, наблюдалась в Ямало-Ненецком автономном округе $(0,71)$, Камчатском крае $(2,15)$, Архангельской области $(2,80)$, Республике Карелия $(5,44)$, Мурманской $(7,24)$ и Магаданской $(15,79)$ областях, Республике Коми $(17,05)$ и Сахалинской области $(19,47)$. Эти регионы достигли целевого показателя конкурентоспособности (таб.3).

Крайне низкая конкурентоспособность в сфере теплоснабжения зафиксирована в Ненецком $(81,74)$, Чукотском $(49,70)$ и Ханты-Мансийском $(33,19)$ автономных округах, а также в Республике Саха $(27,24)$.
За период с 2016 по 2019 годы развитие конкуренции в теплоснабжении по регионам Севера России происходило более равномерно практически по всем регионам Севера России (рис.1). Наибольший скачек в сторону целевых показателей произошел в Мурманской $(-23,7)$ и Сахалинской $(-6,02)$ областях (рис. 3).

Такая ситуация вызвана тем, что в малых населенных пунктах часто наблюдается высокий износ объектов водоснабжения и теплоснабжения, с помощью которых поставляются коммунальные ресурсы, а также большими долгами по жилищно-коммунальным услугам. Отягощающим фактором является то, что эта задолженность имеет кумулятивный эффект — она накапливается с течением времени. Данная проблема с каждым годом растёт. 
Развитие конкуренции в теплоснабжении по регионам Севера России, за 2016-2019 гг., \%*

\begin{tabular}{|l|c|c|c|c|c|}
\multirow{2}{*}{ Регионы } & \multicolumn{2}{|c|}{ Доля полезного отпуска ГУП/МУП по отношению к общему полезному отпуску в субъекте РФ, \% } & Изменение показателя \\
\cline { 2 - 6 } & 2016 & 2018 & $2016-2019$ гг., п.п. \\
\hline Республика Карелия & 2,58 & 2017 & 4,25 & 5,44 & 2,86 \\
\hline Республика Коми & 5,99 & 2,63 & 12,34 & 17,05 & 11,06 \\
\hline Архангельская область & 4,71 & 4,59 & 4,45 & 2,80 & $-1,92$ \\
\hline Ненецкий АО & 80,67 & 82,78 & 83,61 & 81,74 & 1,07 \\
\hline Мурманская область & 30,94 & 31,57 & 33,50 & 3,24 & $-23,70$ \\
\hline Ханты-Мансийский АО & 33,19 & 32,70 & 32,47 & 3,19 & 0,00 \\
\hline Ямало-Ненецкий АО & 1,07 & 0,69 & 0,69 & 271 & $-0,36$ \\
\hline Республика Саха (Якутия) & 26,84 & 31,62 & 24,63 & 2,15 & 0,40 \\
\hline Камчатский край & 3,17 & 1,95 & 3,01 & 15,79 & $-1,02$ \\
\hline Магаданская область & 14,57 & 14,56 & 12,45 & 19,47 & 1,22 \\
\hline Сахалинская область & 25,49 & 19,37 & 19,71 & 49,70 & $-6,02$ \\
\hline Чукотский АО & 49,48 & 49,54 & 49,75 & & 0,22 \\
\hline
\end{tabular}

*Расчеты автора по данным Федеральной антимонопольной службы РФ.

Электронный ресурс. Режим доступа: https://fas.gov.ru

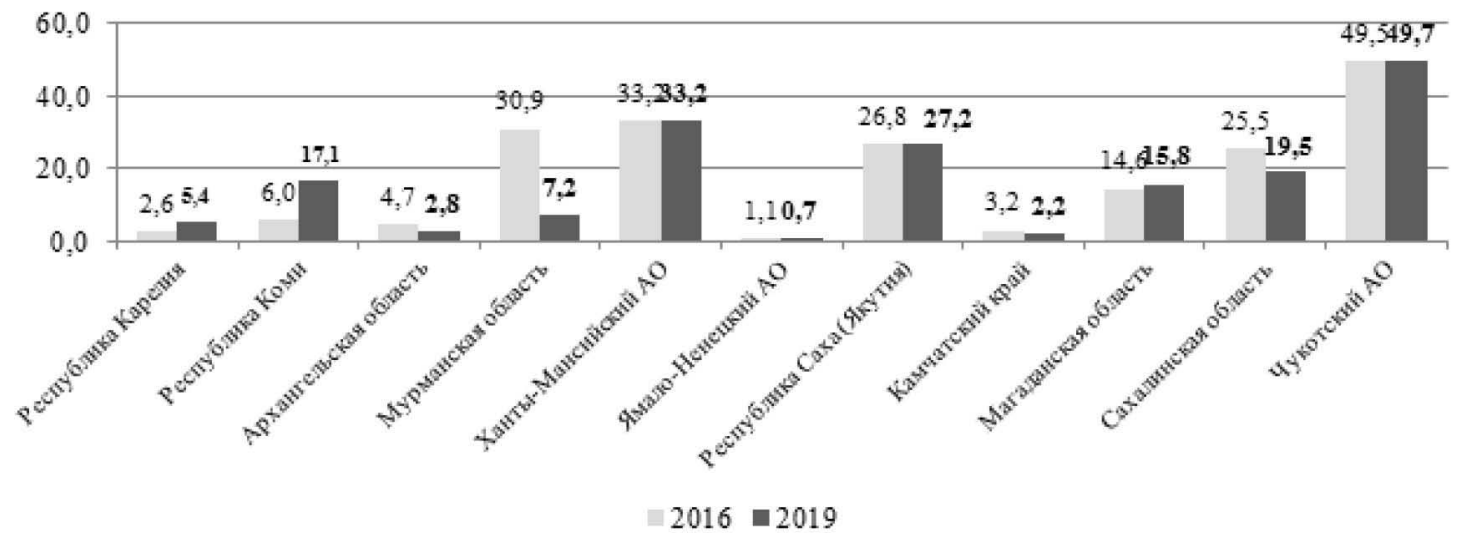

Рис. 3. Изменение показателя развития конкуренции в теплоснабжении

по регионам Севера России, за 2016-2019 гг., \%

У администрации муниципальных образований нет бюджетной возможности самостоятельно обновлять объекты жилищно-коммунального хозяйства или строить новые, а включение капитальных затрат в тариф приведет к их сильному росту, что недопустимо. Закон о концессионных соглашениях предусматривает способы, позволяющие распределить расходы между собственником государственного имущества и частным инвестором [17]. В такой ситуации инвестировать в отрасль не выгодно, отсюда управлять и эксплуатировать объекты хочет все меньшее число компаний. Несмотря на выстроенную законодательную систему концессионных отношений между органами публичной власти и инвесторами, ее широкое применение осложняется наличием высоких рисков как для концедента, так и для концессионера. По оценкам экспертов, сложившаяся ситуация привела к тому, что только 3\% концессионных проектов может быть реализовано без государственной поддерж- ки, 10\% - с поддержкой в виде повышения процентной ставки Центрального банка Российской Федерации на 4\%, 14\% - посредством субсидирования процентной ставки, а 73\% - не могут быть реализованы без государственной помощи [18].

Общий размер образовавшейся за год задолженности за услуги жилищно-коммунального хозяйства напрямую зависит от численности населения, здесь наиболее точную картину платежной дисциплины дает рейтинг регионов по величине прироста долга на душу населения. Среднедушевой показатель по России составил 826 руб. / чел. (в 2017 г. - 740 руб.), но в 44 регионах страны эта цифра выше. В северных регионах антилидерами рейтинга стали Чукотский автономный округ: каждый житель этого субъекта РФ в 2018 г. недоплатил коммунальщикам в пять раз больше, чем в среднем по стране - 4429 руб. Далее идут Мурманская область (3011 
руб.), Камчатский край (2891 руб.) и Республика Коми (2879 руб.) [19].

При этом стоит отметить, что не во всех регионах тарифы покрывают 100\% стоимости услуг. Существенно заниженные тарифы отмечаются в северных регионах с суровыми климатическими условиями, где затраты ресурсосбытовых компаний и потребление ресурсов, например, для обогрева жилья, особенно высоки. Так в Чукотском автономном округе (действующий тариф покрывает лишь 29,4\% реальной стоимости услуг), Республике Саха (Якутия) (45,5\%), Ямало-Ненецком автономном округе $(47,8 \%)$, Ненецком автономном округе и Архангельской области (56,1\%), Магаданской области $(60,7 \%)$. Однако это не помогает жителям избежать долгов: размер образовавшейся в 2018 г. задолженности на душу населения в этих регионах в 2-4 раза выше, чем по стране [20].

Одним из наиболее действенных способов по сокращению задолженности населения за потребленные жилищно-коммунальные услуги были предприняты с 1 марта 2015 года, когда долги по оплате услуг ЖКХ стали отражаться в кредитной истории. Поправки в ФЗ - 218 ст. 5, разрешили предприятиям ЖКУ передавать сведения о просроченных платежах в национальное бюро кредитных историй (НБКИ). [21]. Долги ЖКХ в кредитной истории показали, что 2/3 из тех, кто не платит за воду и тепло активно пользуются кредитами. По данным Национального бюро кредитных историй (НБКИ), средний размер установленной судом задолженности граждан находится на уровне 46 тыс. рублей. Что касается юридических лиц, здесь средний показатель составляет 594 тыс. рублей. [22]. Статус должника чреват многими проблемами, от суда и неодобренного кредита до невыезда за границу. Информация о не погашенной по решению суда задолженности граждан за услуги ЖКХ хранится в течение десяти лет и доступна всем кредиторам - банкам, микрофинансовым организациям, ломбардам. Кредитная история является, по сути, документом о состоянии финансовой репутации и платежной дисциплины гражданина. Взаимодействие между предприятиями ЖКХ и НБКИ является одним из наиболее действенных способов по сокращению задолженности населения за потребленные жилищно-коммунальные услуги. Для организаций в сфере ЖКХ передача данных о должниках в НБКИ позволила улучшить экономику и конкурентоспо- собность регионов.

По состоянию на 01.01.2018 года число злостных неплательщиков (не погасивших долг за услуги ЖKX по решению суда), информация о которых была передана в Национальное бюро кредитных историй (НБКИ) предприятиями ЖKX, достигло 24,2 тысяч человек. Таким образом, по сравнению с началом 2017 года количество граждан, информация о которых была передана в НБКИ, увеличилось в 2,2 раза. По состоянию на 01.01.2018 года задолженность этих граждан за жилищно-коммунальные услуги составила около 1,3 млрд. рублей, увеличившись за 2017 год почти в 2,2 раза (на 01.01.2017 года около 600 млн. руб.). При этом средний размер их долга находится на уровне около 50 тыс. рублей. В свою очередь, количество источников информации, на постоянной основе передающих в НБКИ данные о неплательщиках, с начала года увеличилось на 66,7\% и достигло 100 предприятий ЖКХ из 40 регионов РФ (таб.4).

По данным Национального бюро кредитных историй, средняя сумма долга за ЖКУ, которую взыскивают через суд, составляет 43 тыс. руб.

Чтобы снизить задолженность перед поставщиками ресурсов в 2018 году вышел закон о прямых расчетах граждан с ресурсоснабжающими организациями. [23]. Документ был призван убрать посредника в виде управляющей компании. Этот же закон запретил распределять долг одних жителей между другими жителями дома, чем коммунальные хозяйства ранее успешно пользовались.

С 1 января 2019 года произошло повышение ставки налога на добавленную стоимость с 18\% до 20\%, что привело к ухудшению ситуации в отрасли. Убытки поставщиков спровоцировали рост долгов в ЖКХ. Решением в этом случае стало повышение тарифов за жилищнокоммунальные услуги.

В январе 2020 года Минстрой России опубликовал проект программы господдержки модернизации объектов жилищно-коммунального хозяйства ЖКХ с износом более 60\% в субъектах РФ [24]. Согласно документу, средства на модернизацию из федерального бюджета планируется перечислять в регионы через оператора, которого определит правительство России. Субсидии пойдут на объекты коммунальной инфраструктуры в виде компен-

Динамика передачи в НБКИ данных о должниках в РФ

Таблица 4

\begin{tabular}{|c|c|c|c|c|}
\hline Дата & Кол-во источников & Регионов & Кол-во переданных субъектов,тыс. шт. & Из них юридических лиц, тыс. шт. \\
\hline 01.01 .2016 & 10 & 5 & 4,1 & 0,4 \\
\hline 01.01 .2017 & 60 & 20 & 11,0 & 1,2 \\
\hline 01.01 .2018 & 100 & 40 & 24,2 & 2,5 \\
\hline
\end{tabular}


сации процентной ставки по кредиту, на модернизацию объектов и компенсацию затрат концессионера на реконструкцию объектов. Реализация программы модернизации коммунальной инфраструктуры «60+» начнется с 2021 года и будет осуществляться на конкурсной основе только на малые города с численностью населения до 100 тыс. человек. Ее субсидирование возможно только для тех объектов, которые ранее не получали финансовой поддержки из федерального бюджета.

\section{Выводы и предложения:}

Для сглаживания проблем в сфере жилищно-коммунального хозяйства в настоящее время принимаются и инициируются различные механизмы.

В целях вовлечения непривлекательных объектов коммунального ресурса в хозяйственный оборот, в том числе в малых городах и поселениях, и привлечения инвестиций для их модернизации предлагается внести изменения в действующий Закон о концессионных соглашениях. Необходимо предусмотреть возможность проведения несколькими муниципальными образованиями совместного конкурса, что даст возможность потенциальным инвесторам заключать концессионные соглашения сразу с несколькими муниципальными образованиями одновременно. Это позволит объединять в объект концессий как привлекательные, так и непривлекательные с точки зрения инвестора объекты, что будет являться дополнительной возможностью вовлечения непривлекательных объектов, находящихся в государственной или муниципальной собственности.

Еще одним механизмом защиты инвестора является компенсация недополученных доходов концессионера или возможность продления срока действия концессионного соглашения. Эти меры будут направлены на обеспечение стабильных условий деятельности концессионера и возможности предоставления государственных или муниципальных гарантий в соответствии с бюджетным законодательством.

Предлагается рассмотреть вопрос о внесении изменений в Федеральный закон от 7 декабря 2011 года № 416-Ф3 «О водоснабжении и водоотведении» в части расширения в отрасли водоснабжения и водоотведения различных способов управления имуществом водохозяйственного комплекса посредством применения форм государственно-частного партнерства.

Передача данных о долгах в бюро кредитных историй уже стала для многих предприятий энергетики и ЖКХ одним из наиболее эффективных инструментов работы по взысканию задолженности. Однако пока этот инструмент не может выполнять функцию предупреждения возникновения задолженности за жилищно-комму- нальные услуги. Прежде всего, потому, что по закону «О кредитных историях» направлять в БКИ информацию о наличии задолженности возможно только по истечении 10 дней после вступления в силу решения суда. Таким образом, действующий механизм не позволяет полностью раскрыть потенциал взаимодействия предприятий ЖКХ и энергетики с НБКИ. Предлагается внести изменения в действующее законодательство и допустить передачу данных о платёжной дисциплине потребителей энергоресурсов или услуг ЖКХ в бюро кредитных историй без привязки к решению суда. Такое изменение поможет не только стимулировать потребителей к своевременным расчётам, но и поможет формировать более полную кредитную историю.

Еще одна из инициатив заключается в том, чтобы поставлять коммунальные услуги должникам в связи с началом отопительного периода только после полного погашения задолженности. Необходимо разработать механизмы для борьбы с самовольным подключением тепла и ввести административную ответственность за изготовление, продажу и рекламу устройств, искажающих информацию на счетчиках. Однако технические характеристики инженерных систем старых многоквартирных домов таковы, что для приостановления ЖКУ по горячему водоснабжению необходимо обеспечение доступа в жилое помещение. Кроме того, если там прописан несовершеннолетний ребенок, отключать отопление и горячую воду законодательством запрещено.

Наказание рублем - самая распространенная практика при попытках заставить должника оплатить коммунальные счета. Последний раз размер штрафов для должников увеличился в 2016 году. До этого за каждый день просрочки, начиная со второго месяца, начислялись пени в размере 1/300 ставки рефинансирования Центробанка. По новому закону, начиная с четвертого месяца штраф, увеличивается больше чем в два раза до $1 / 130$.

Штрафы - не единственный законный способ «выбивания» долгов. В случае если должник не соглашается оплачивать коммунальные услуги, управляющие компании могут их отключить. По закону, перекрыть доступ можно к свету, электроэнергии, газу и горячей воде. В борьбе с долгами и должниками Постановлением Пленума Верховного Суда РФ от 27.12.2016 года № 62 «О некоторых вопросах применения судами положений Гражданского процессуального кодекса Российской Федерации и Арбитражного процессуального кодекса Российской Федерации о приказном производстве» (п. 1.1 ч. 1 ст. 135 ГПК РФ), предоставляется управляющим организациям право списывать денежные средства граждан с их банковских карт. При этом, по закону с должника не могут снять более половины зарплаты или других доходов. Однако если пройдет трехлетний срок исковой 
давности или должника не найдут, компания признает задолженность «безнадежной к взысканию» и спишет ее. Попытки заставить людей платить за более ранние долги пресечены п. 32 Постановления Пленума ВС РФ от 27 июня 2017 г. № 22, согласно которому платежи граждан могут засчитываться только за периоды, по которым срок исковой давности не истек.

Управляющие компании и ресурсосберегающие организации пробовали продавать долги коллекторским агентствам, которые применяли внеправовые способы воздействия на должников. Однако из-за многочисленных жалоб пользователей услуг ЖКХ с 1 августа 2019 году Госдума приняла закон, запретивший уступку долгов коллекторам. [25]. Выход - продавать долги перед ресурсосберегающими организациями и управляющими компаниями на конкурсах для их взыскания через службу частных приставов.

Из анализа судебных решений по искам о взыскании долгов за ЖКХ масштаб проблемы меняется от региона к региону. Рост задолженности населения за коммунальные услуги может быть связан как с повышением их стоимости, так и с падением уровня доходов граждан, а также нередко с низкой финансовой дисциплиной потребителей. Оплата счетов жилищно-коммунальных услуг - одна из самых больших статей расходов россиян после продуктов питания. Так как счета за поставку данного ресурса с каждым годом растут, опережая уровень заработной платы и пенсионного обеспечения, определенные категории граждан не в состоянии оплачивать их в полном объеме. Законодательство предусматривает поддержку для незащищенных слоев населения. Она осуществляется двумя способами: путем применения льгот, которые уменьшают размер платежей и путем субсидирования.

В марте 2020 года собираемость платежей за жилищно-коммунальные услуги резко сократилась из-за режима самоизоляции. Многие граждане, в силу различных причин отрезаны от сервиса, с помощью которого можно оплатить услуги. Отсюда произошло падение собираемости платежей по населению на $30 \%$. Что касается предприятий, в том числе бюджетных, там падение еще значительнее - 45-50\%. Правительство объявило о новых мерах поддержки населения и бизнеса в условиях негативного влияния на экономику коронавирусной инфекции. Пандемия ухудшила финансовое благополучие граждан. Помимо общего сокращения доходов, население несет дополнительные издержки в виде повышенных счетов ЖКУ, которые обусловлены длительным пребыванием дома. Был введен особый порядок оплаты ЖКУ и предоставления коммунальных услуг: до конца 2020 года не начисляются штрафные санкции за неоплаченные коммунальные услуги; их не станут отключать за долги; не будет начисляться пеня за просрочку взносов на капитальный ремонт. Семьям с низкими доходами до 1 октября без дополнительных подтверждений продлевается право получать субсидии на оплату жилья и услуг ЖКХ. В такой ситуации участники коммунального рынка бьют тревогу, они выходят с обращениями на всех уровнях, так как несут дополнительные расходы, но не имеют возможности компенсировать даже прежний уровень предоставленных ресурсов и услуг. Минстрой России обратился в правительство с просьбой поддержать жилищно-коммунальное хозяйство. В частности, предлагается включить жилищно-коммунальное хозяйство в список отраслей, наиболее пострадавших от COVID-19, так как на управляющие компании легла большая и дополнительная нагрузка: увеличилась периодичность уборки, проводится дополнительная дезинфекция помещений из-за коронавируса. Начался сезон подготовки к следующему отопительному периоду 2020-2021 годов. Все запланированные мероприятия по подготовке внутридомовой инфраструктуры к зиме должны быть выполнены в установленные сроки. Отсюда может быть очень серьезный провал в поступлениях от граждан по коммунальным услугам, который затронет и ресурсоснабжающие организации, и управляющие компании.

\section{ЛИТЕРАТУРА}

1. Указ Президента РФ от 21.12.2017 N 618 «0б основных направлениях государственной политики по развитию конкуренции» (вместе с «Национальным планом развития конкуренции в Российской Федерации на 2018 - 2020 годы»). http://www.consultant.ru

2. Электронный ресурс // ХІХ Всемирный фестиваль молодежи и студентов. 2017. 15 окт. https://ru.wikipedia.org/

3. Радаев В.В. Социология рынков: к формированию нового направления. М., 2003.328 с.

4. Конкурентное преимущество: как достичь высокого результата и обеспечить его устойчивость / Майкл Е. Портер; пер. с англ. [Е. Калинина]. - М. : Альпина Бизнес Букс, 2005 (ОАО Можайский полигр. комб.). - 714 с.

5. Робинсон Дж. Экономическая теория несовершенной конкуренции. М.: Экономика, 2006. 390 с.

6. Шумпетер Й. Капитализм, социализм и демократия / Й. Шумпетер. М.: Знание, 2005. 419 с.

7. И.А. Данилов, Е.В. Волкова. Ретроспективный анализ трактования терминов «конкурентоспособность» и «конкурентное преимущество» отечественными и зарубежными авторами. Вестник Челябинского государственного университета. 2010. № 3 (184). Экономика. Вып. 24. С. 126-133.

8. Завьялов П.С. Конкуренция — неотъемлемое свойство развитого рынка / П.С. Завьялов // Маркетинг. 2007. № 5. С. 2-14. 
9. Долинская, М.Г. Маркетинг и конкурентоспособность промышленной продукции / М.Г. Долинская, М.А. Соловьёв. М. : Изд-во стандартов, 1991. 128 с.

10. Фатхутдинов, Р.А. Стратегическая конкурентоспособность / Р.А. Фатхутдинов. М.: Экономика, 2005. 505 с.

11. Malecki E.J. Knowledge and regional competitiveness. - Erdkunde, 2000, $54 \mathrm{c}$.

12. Хайек Ф. А. фон. Конкуренция как процедура открытия /Ф.А. фон. Хайек // Мировая экономика и международные отношения. - 1989. - № 12.

13. Ведин Н.В. Диалектика сотрудничества и конкуренции в хозяйственной эволюции общества: автореф. Дис. ... д-ра экон. наук. Казань, 2007. 44 с.

14. Терешин А.В. Интеграция партнерства и конкуренции в предпринимательстве//Этап: экономическая теория, анализ, практика. 2015. №5.С.127-136.

15. Федеральный закон от 12.01.1996г.N7-Ф3 «0 некоммерческих организациях». http://www.consultant.ru/

16. Распоряжение Правительства РФ № 1738-р «Стандарт развития конкуренции в субъектах РФ». http://www.consultant.ru/

17. Федеральный закон «0 концессионных соглашениях» 0 т 21.07.2005 N 115-Ф3.

18. «Актуальные вопросы модернизации объектов коммунальной инфраструктуры с высокой степенью износа: законодательные новации и правоприменительная практика». Официальный сайт Правительства Российской Федерации.

19. http://council.gov.ru/activity/activities/roundtables/111947/Фин. Экспертиза.https://finexpertiza.ru/press-service/researches/2019/zadolzh-uslugi-zkh/

20. Известия iz: https://iz.ru/765335/svetlana-volokhina-tatiana-gladysheva/dolgi-za-zhkkh-v-rossii-vyrosli-do-14-trln-rublei

21. Федеральный закон Российской Федерации 30 декабря 2004 года N 218-Ф3 «0 кредитных историях».

22. Официальный сайт БКИ: https://mycreditinfo.ru/

23. Федеральный закон «0 внесении изменений в Жилищный кодекс Российской Федерации» от 03.04.2018 N 59-Ф3.

24. www.minstroyrf.ru

25. Федеральный закон от 26.07.2019 № 214-Ф3 «0 внесении изменений в статьи 155 и 162 Жилищного кодекса Российской Федерации и статью 1 Федерального закона «0 защите прав и законных интересов физических лиц при осуществлении деятельности по возврату просроченной задолженности и 0 внесении изменений в Федеральный закон «0 микрофинансовой деятельности и микрофинансовых организациях».

○ Тихомирова Валентина Валентиновна (tikhomirova@iespn.komisc.ru).

Журнал «Современная наука: актуальные проблемы теории и практики»

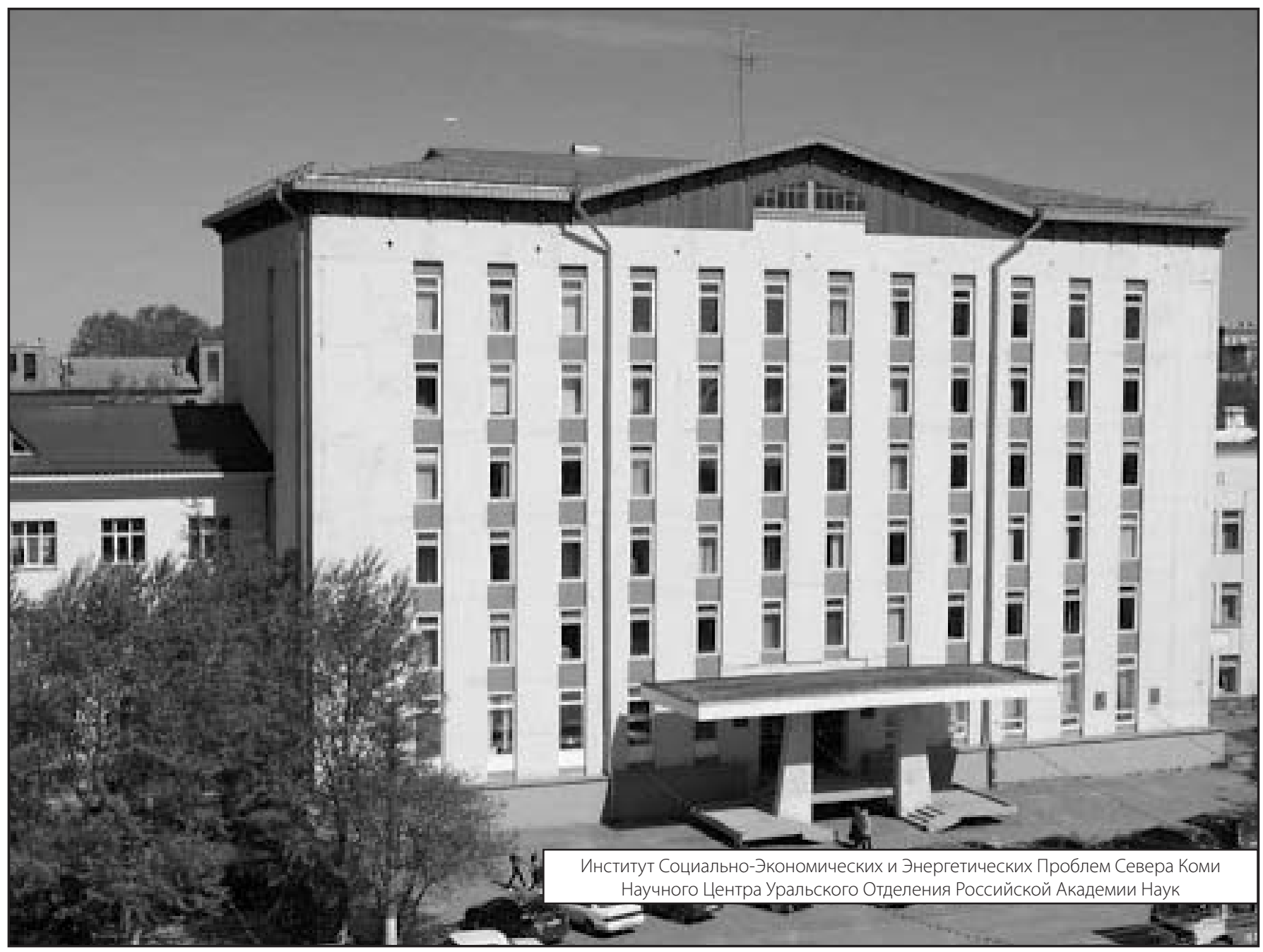

